\title{
Effect of Dietary Micronutrients on Physiological Responses and Biochemical Profile in Growing Cross Bred Calves
}

\author{
Gaurav Thorat*, Anjali Khare, S.S. Lathwal, Mamata Joysowal, \\ A. Aziz and Chander Datt \\ Livestock Production Management Division, \\ ICAR-National dairy Research Institute, Karnal 132001, India \\ FES, FFSc, WBUAFS, Kol-94, India \\ *Corresponding author
}

Key w or d s
Calves,
Micronutrient,
Niacin, Iodine, Heat
stress
Article Info
$\begin{aligned} & \text { Accepted: } \\ & \text { 06 June } 2018 \\ & \text { Available Online: } \\ & \text { 10 July } 2018\end{aligned}$

\section{Introduction}

India cattle population 199.1 million in which crossbred contribute 39.73 millions The exotic/crossbred milch cattle increased from
14.4 million to 19.42 million on the percentage basis $34.78 \%$ (19th Livestock Census- 2012) The average daily milk yield for crossbred cattle is $7.1 \mathrm{~kg}$ per day, but still significantly lesser than the United Kingdom, 
Climate change is perceived as a major threat to the survival of many species and ecosystems as well as to the financial sustainability of pastoral systems in various parts of the world (Gaughan et al., 2009), especially in developing countries. Recent economic studies have suggested severe losses if the current management systems are not changed as a result of climate change (Nardone et al., 2010).

Agricultural animal productivity is maximized within narrow environmental conditions. When the temperature is either below or above the respective threshold values, efficiency and thus profitability are compromised because nutrients are diverted from productive purposes to maintain a safe body temperature (Baumgard and Rhoads, 2013).

Farm animals have known zones of thermal comfort that primarily dependent on the species, physiological status of the animals, relative humidity and the severity of solar radiation. High environmental temperature and humidity are detrimental to the productivity of commercial farm animals. Heat stress can occur in dairy cattle when temperatures are above $25^{\circ} \mathrm{C}$ when combined with high humidity, low air flow and direct sun light (Hahn, 1999). Cold stress increases dry matter intake. Cattle's maintenance energy requirements increase by 1 to $1.5 \%$ for each degree below the critical temperature (Johnson, 1986). Nutritional management plays an important role in reducing the effects of seasons and have beneficial effect on body growth, physiological responses of the animal.Niacin in ration helps in coping with heat stress as it increase the peripheral circulation, increase sweating and stabilize cellular protein structure (Benyo et al., 2006). The vitamin $\mathrm{E}$ also increases sweating that removes heat from the cattle. (Di constanzo et al., 1997). Zinc plays an integral role in regulating the wide variety of body functions including cell division, growth, hormone production, metabolism, appetite control and immune function. Chromium demand increases during stress e.g. fatigue, trauma, gestation and different forms of nutritional (high-carbohydrate diet), metabolic, physical, and emotional stress as well as environmental effects. To overcome these problem zinc, niacin, iodine, chromium and vitamin $\mathrm{E}$ to be supplemented in our study is discussed below

\section{Materials and Methods}

\section{Ethical approval}

The experiment was carried out according to the National Regulations on Animal Welfare and the Institutional Animal Ethical Committee.

\section{Study design}

The study was carried out at Livestock Research Center, National Dairy Research Institute, Karnal for 150 days on 24 female KF calves distributed randomly into 4 groups of 6 animals each based on their body weight and age in a randomised block design (RBD). At the beginning of the experiment, the average age and body weight of the calf in control group $\mathrm{T}_{1}$ were $11.75 \pm 1.31$ Month and $116.68 \pm 16.35 \mathrm{~kg}$, in $\mathrm{T}_{2} 11.53 \pm 0.96$ Month and $117.65 \pm 12.83 \mathrm{~kg}$, in $\mathrm{T}_{3} 11.03 \pm 1.03$ Month115.16 $\pm 14.32 \mathrm{~kg}$, and $\mathrm{T}_{4} 11.86 \pm 0.95$ Month and $116.68 \pm 16.35 \mathrm{~kg}$ respectively. The animals were clinically healthy and kept under the same conditions, with appropriate facilities for feeding and watering. Concentrate mixture, sorghum/maize green fodder and wheat straw were supplied in the ratio of 40: 40: 20 (on DM basis) in all four types rations to meet the requirements (ICAR, 2013). In group $T_{1}$, the concentrate mixture consisted of mineral mixture without iodine. The animals in group $T_{2}$ and $T_{3}$ were supplemented with iodine at 0.25 and $0.5 \mathrm{ppm}$ 
of dietary DM while in group $T_{4}, 4$ micronutrients i.e. chromium, niacin, vitamin E and Zn were supplemented @ 1.5, 60040 and $40 \mathrm{ppm}$, respectively. The Ingredient composition of concentrate mixture has been given in Table 1. The effect of weather parameters, such as temperature and humidity, on the KF calves was expressed in terms of temperature humidity index (THI). Observations for THI were recorded at 8:30 am and 4:22 pm daily. The average THI was fortnightly calculated for the experimental period using the following formula given by U.S. Weather BureauC - wet bulb temperature $\left({ }^{\circ} \mathrm{C}\right)$.

$\mathrm{THI}=0.72\left(\mathrm{db}^{\circ} \mathrm{C}+\mathrm{wb}^{\circ} \mathrm{C}\right)+40.6$

The rectal temperature (RT), respiration rate (RR) and pulse rate (PR) were weekly measured in the morning and in the evening. The RTs $\left({ }^{\circ} \mathrm{F}\right)$ of were recorded using a digital thermometer by inserting 3 inches in the rectum for about $2 \mathrm{~min}$. The RR per minute was recorded by counting the movement of flank, i.e., one outward and inward movement considered as one respiration. The PR per minute was counted by palpating coccygeal artery. Blood samples were collected fortnightly, and plasma was separated and stored at $-20^{\circ} \mathrm{C}$ for estimation of cortisol levels using commercially available kits.

\section{Statistical analysis}

The experimental data generated were analyzed by ANOVA using the statistical software program SPSS (SPSS Inc., Chicago, Illinois, USA). Data on the were analyzed using three-way ANOVA adopting repeated measures procedure using GLM of SPSS; the analysis included between-subjects main effect of treatment and season, within-subjects main effect of period of sampling and within subject main effect of season interaction between the periods of sampling $\times$ treatment, interaction between the periods of sampling $x$ season, between the season $\times$ treatment, and interaction between treatment $x$ season $\times$ period. The effects were considered to be significant at $p<.05$.

\section{Results and Discussion}

The values for THI are summarized in Table 2. The maximum and minimum THI during morning time ranged from $76.18 \pm 0.28$ to $49.48 \pm 1.05$ respectively throughout the experimental period. During afternoon, the corresponding THI ranged from $85.60 \pm 0.48$ and $61.42 \pm 0.6$ which were higher than the morning THI. The lowest morning THI was observed in II fortnight whereas highest morning was observed in fortnight $\mathrm{X}$. The THI throughout the experimental period varied from 49.48-76.18 and 61.42-85.60 during morning and afternoon, respectively. THI below 72 indicating cold stress on the animals Kumar (2003) and Gantner et al., (2011).

The experimental animals were under more cold stress during I-V Fortnight as the lowest THI values were observed in these months. The effect on the animal performance was greatest when THI exceeded 76 (West,1993). Fuquary (1981) and Kumar (2003) stated that degree of heat stress on the cattle and buffalo can be estimated by the THI value and THI above 72 is used to indicate heat stress on animals. The experimental animals were under more heat stress on VI-X Fortnight as the highest THI values were observed in these months.

\section{Physiological parameter}

The mean morning and afternoon rectal temperature $\left({ }^{\circ} \mathrm{F}\right)$ in summer and winter has been presented in the Table 3. There were no significant differences among the treatments in both the season. The morning rectal temperature was significantly $(\mathrm{P}<0.05)$ higher 
in summer $(101.16 \pm 0.07)$ as compare to winter $(100.87 \pm 0.07)$.

There was significant $(\mathrm{P}<0.01)$ differences observe Afternoon rectal temperature in summer season among the overall treatment groups. Significantly lower afternoon rectal temperature was seen in group $\mathrm{T}_{4}$ $\left(101.96^{\mathrm{a}} \pm 0.10\right)$ and higher value in group $\mathrm{T}_{1}$ $\left(102.24^{\mathrm{b}} \pm 0.14\right) \quad$ group, with intermediate values observed in $\mathrm{T}_{2}\left(102.14^{\mathrm{ab}} \pm 0.18\right)$ and $\mathrm{T}_{3}$ $\left(102.16^{\mathrm{ab}} \pm 0.15\right)$. In winter there is no significant difference observed among the treatment groups. The afternoon rectal temperature was significantly $\quad(\mathrm{P}<0.05)$ higher in summer $\left(102.99^{\mathrm{B}} \pm 0.08\right)$ as compare to winter $\left(101.45^{\mathrm{A}} \pm 0.06\right)$.

Similar to our study Verma and Husain (1986) showed a significant rise in the rectal temperature in buffaloes during the summer season. Mayengbam (2008) in crossbred cattle also showed rise in RT during climatic chamber exposure $\left(40\right.$ and $45^{\circ} \mathrm{C}$ and $50 \%$ RH). However Singh et al. (2009) studied the effect of of zinc causes decreases non significantly rectal temperature in summer season. Contrary to our study Patel (2015) supplemented zinc to pregnant KF cows and found no significant variation in rectal temperature. The mean morning and afternoon pulse rate (per min) in summer and winter has been presented in the Table 3 .

Morning pulse rate were there was no significant deferens observe in summer and winter pulse rate however there is significant $(\mathrm{P}<0.05)$ differences among the overall treatment groups. Significantly lower value was seen in $\left(65.42^{\mathrm{a}} \pm 0.75\right) \mathrm{T}_{4}$ group compare to $\left(66.17^{\mathrm{b}} \pm 0.63\right) \quad \mathrm{T}_{3}, \quad\left(66.98^{\mathrm{b}} \pm 0.74\right) \quad \mathrm{T}_{2}$ and $\left(66.20^{\mathrm{b}} \pm 0.80\right)$ group $\mathrm{T}_{1}$. The mean morning pulse rate was significantly $(\mathrm{P}<0.01)$ higher in winter $\left(69.47^{\mathrm{A}} \pm 0.33\right)$ as compare to summer $\left(62.81^{\mathrm{B}} \pm 0.54\right)$.
There afternoon pulse rate significant $(\mathrm{P}<0.01)$ differences among the overall treatment groups. Significantly lower afternoon pulse rate was seen in group $\mathrm{T}_{4}$ and higher value in group $\mathrm{T}_{3}$ group, with intermediate values observed in $T_{2}$ and $T_{1} B u t$ In winter season and summer season there is no significant difference observed among the treatment groups. The afternoon pulse rate was significantly $\quad(\mathrm{P}<0.05)$ higher in summer $\left(71.48^{\mathrm{B}} \pm 0.69\right)$ as compare to winter $\left(62.65^{\mathrm{A}} \pm 0.37\right)$. The result are accordance with those reported by Gangwar et al., (1988) who also found significant higher in average value of pulse rate during summer and lower during winter season. Gaalas (1945) and Blaxter and Prince (1945) showed an increase in PR with rise in environmental temperature in swamp. Joshi et al., (1982) showed that PR increased after introduction of buffalo to hot environment. Opposite to our study Patel (2015) supplemented zinc to pregnant KF cows and found no significant variation in pulse rate.

The mean morning and afternoon respiration rate in summer and winter has been presented in the Table 3. There is no significant difference observe among treatment and control and also In morning respiration rate winter season and summer season. The mean morning respiration rate was significantly $(\mathrm{P}<0.01)$ higher in summer $\left(46.32^{\mathrm{B}} \pm 0.59\right) \quad$ as compare to winter $\left(29.32^{\mathrm{A}} \pm 0.35\right)$. Afternoon respiration rate were significant $(\mathrm{P}<0.01)$ differences among the overall treatment groups. Significantly lower afternoon respiration rate was seen in group $\mathrm{T}_{4}\left(45.66^{\mathrm{a}} \pm 2.05\right)$ and higher value in group $\mathrm{T}_{1}\left(48.92^{\mathrm{b}} \pm 2.24\right)$. However there is no significant deferens observe in summer and winter respiration rate. The afternoon respiration rate was significantly $(\mathrm{P}<0.05)$ higher in summer $(66.25 \pm 0.74)$ as compare to winter (33.01 \pm 0.40$)$. 
Table.1 THI value of different fortnight and mean value of winter and summer

\begin{tabular}{|c|c|c|c|c|}
\hline & Fortnight & Morning THI & Afternoon THI & Overall Mean \\
\hline \multirow[t]{5}{*}{ Winter THI } & 1 & $53.55 \pm 0.69$ & $66.92 \pm 0.46$ & $60.24 \pm 6.68$ \\
\hline & 2 & $49.48 \pm 1.05$ & $61.42 \pm 0.61$ & $55.45 \pm 5.97$ \\
\hline & 3 & $55.85 \pm 0.89$ & $65.71 \pm 0.61$ & $60.78 \pm 4.93$ \\
\hline & 4 & $54.50 \pm 1.15$ & $68.61 \pm 0.81$ & $61.56 \pm 7.05$ \\
\hline & 5 & $56.50 \pm 0.65$ & $70.60 \pm 0.66$ & $63.55 \pm 7.05$ \\
\hline \multicolumn{2}{|c|}{ MEAN } & $53.98 \pm 1.23$ & $66.65 \pm 1.54$ & $60.31 \pm 6.34$ \\
\hline \multirow[t]{5}{*}{ Summer THI } & 6 & $58.94 \pm 0.90$ & $70.62 \pm 0.87$ & $64.78 \pm 5.84$ \\
\hline & 7 & $68.14 \pm 0.71$ & $80.18 \pm 0.64$ & $74.16 \pm 6.02$ \\
\hline & 8 & $69.41 \pm 1.41$ & $82.28 \pm 0.96$ & $75.84 \pm 6.44$ \\
\hline & 9 & $71.96 \pm 0.40$ & $82.62 \pm 0.41$ & $77.29 \pm 5.33$ \\
\hline & 10 & $76.18 \pm 0.28$ & $85.60 \pm 0.48$ & $80.89 \pm 4.71$ \\
\hline \multicolumn{2}{|c|}{ MEAN } & $68.93 \pm 2.85$ & $80.26 \pm 2.56$ & $74.59 \pm 5.67$ \\
\hline
\end{tabular}

Table.2 Proximate composition of diet (fed on \% DM basis)

\begin{tabular}{|c|c|c|c|c|}
\hline Parameter & $\begin{array}{c}\text { Concentrate } \\
\text { Mixture }\end{array}$ & Sorghum & Maize fodder & Wheat straw \\
\hline DM & 90.99 & 30.92 & 13.98 & 92.26 \\
\hline OM & 92.73 & 88.81 & 89.38 & 88.44 \\
\hline CP & 20.34 & 10.58 & 10.75 & 2.27 \\
\hline Total ash & 08.26 & 11.19 & 10.62 & 11.56 \\
\hline EE & 3.99 & 2.35 & 2.66 & 0.71 \\
\hline NDF & 33.96 & 54.62 & 47.55 & 72.97 \\
\hline ADF & 13.81 & 38.24 & 36.21 & 54.62 \\
\hline TDN* & 68.38 & 60.42 & 62.66 & 45.34 \\
\hline
\end{tabular}


Table.3

\begin{tabular}{|c|c|c|c|c|c|c|c|c|c|c|c|c|}
\hline Fortnight & $T_{1}$ & $\mathrm{~T}_{2}$ & $T_{3}$ & $\mathrm{~T}_{4}$ & Period mean & $\mathrm{T}$ & $\mathrm{P}$ & $\mathrm{S}$ & $\mathrm{T}^{*} \mathrm{P}$ & $T^{*} \mathrm{~S}$ & $\mathrm{~S} * \mathrm{P}$ & $\mathrm{T}^{*} \mathrm{P} * \mathrm{~S}$ \\
\hline \multicolumn{13}{|c|}{ Morning Rectal temperature $\left({ }^{0} \mathbf{F}\right)$} \\
\hline WinterMean & $100.88 \pm 0.15$ & $100.75 \pm 0.16$ & $100.93 \pm 0.10$ & $100.94 \pm 0.10$ & $100.87^{\mathrm{A}} \pm 0.07$ & 0.504 & 0.005 & 0.004 & 0.283 & .394 & 0.021 & 0.153 \\
\hline $\begin{array}{l}\text { Summer } \\
\text { Mean }\end{array}$ & $100.93 \pm 0.16$ & $101.28 \pm 0.13$ & $101.19 \pm 0.15$ & $101.26 \pm 0.16$ & $101.16^{\mathrm{B}} \pm 0.07$ & & & & & & & \\
\hline Overall mean & $100.90 \pm 0.11$ & $100.99 \pm 0.11$ & $101.04 \pm 0.09$ & $101.09 \pm 0.09$ & & & & & & & & \\
\hline \multicolumn{13}{|c|}{ Afternoon Rectal temperature $\left({ }^{0} \mathrm{~F}\right)$} \\
\hline WinterMean & $101.50 \pm 0.12$ & $101.52 \pm 0.11$ & $101.30 \pm 0.13$ & $101.51 \pm 0.09$ & $101.45^{\mathrm{A}} \pm 0.06$ & 0.008 & $<0.01$ & $<0.01$ & 0.466 & 0.006 & $<0.01$ & 0.123 \\
\hline $\begin{array}{l}\text { Summer } \\
\text { Mean }\end{array}$ & $103.14 \pm 0.17$ & $103.12 \pm 0.16$ & $103.20 \pm 0.14$ & $102.50 \pm 0.14$ & $102.99^{\mathrm{B}} \pm 0.08$ & & & & & & & \\
\hline Overall mean & $102.24^{\mathrm{b}} \pm 0.14$ & $102.14^{\mathrm{ab}} \pm 0.18$ & $102.16^{\mathrm{ab}} \pm 0.15$ & $101.96^{\mathrm{a}} \pm 0.10$ & & & & & & & & \\
\hline \multicolumn{13}{|c|}{ Morning pulse rate (per min) } \\
\hline WinterMean & $70.22 \pm 0.72$ & $70.03 \pm 0.61$ & $70.19 \pm 0.52$ & $67.44 \pm 0.64$ & $69.47^{\mathrm{A}} \pm 0.33$ & 0.04 & $<0.01$ & $<0.01$ & $<0.01$ & 0.085 & $<0.01$ & $<0.01$ \\
\hline $\begin{array}{l}\text { Summer } \\
\text { Mean }\end{array}$ & $61.37 \pm 0.96$ & $63.33 \pm 1.15$ & $63.53 \pm 0.84$ & $63.00 \pm 1.33$ & $62.81^{\mathrm{B}} \pm 0.54$ & & & & & & & \\
\hline Overall mean & $66.20^{\mathrm{b}} \pm 0.80$ & $66.98^{\mathrm{b}} \pm 0.74$ & $66.17^{b} \pm 0.63$ & $65.42^{\mathrm{a}} \pm 0.75$ & & & & & & & & \\
\hline \multicolumn{13}{|c|}{ Afternoon pulse rate (per min) } \\
\hline WinterMean & $62.86 \pm 0.73$ & $63.00 \pm 0.75$ & $63.83 \pm 0.63$ & $60.89 \pm 0.80$ & $62.65^{\mathrm{A}} \pm 0.37$ & 0.002 & $<0.01$ & $<0.01$ & $<0.01$ & 0.929 & $<0.01$ & 0.04 \\
\hline $\begin{array}{l}\text { Summer } \\
\text { Mean }\end{array}$ & $70.93 \pm 1.22$ & $71.67 \pm 1.32$ & $73.10 \pm 1.53$ & $70.20 \pm 1.46$ & $71.48^{\mathrm{B}} \pm 0.69$ & & & & & & & \\
\hline Overall mean & $66.53^{\mathrm{ab}} \pm 0.84$ & $66.94^{\mathrm{ab}} \pm 0.90$ & $68.05^{\mathrm{b}} \pm 0.96$ & $65.12^{\mathrm{a}} \pm 0.98$ & & & & & & & & \\
\hline \multicolumn{13}{|c|}{ Morning respiration rate(per min) } \\
\hline WinterMean & $29.14 \pm 0.56$ & $29.42 \pm 0.79$ & $30.01 \pm 0.60$ & $28.69 \pm 0.79$ & $29.32^{\mathrm{A}} \pm 0.35$ & 0.933 & $<0.01$ & $<0.01$ & $<0.01$ & .277 & $<0.01$ & $<0.01$ \\
\hline $\begin{array}{l}\text { Summer } \\
\text { Mean }\end{array}$ & $47.53 \pm 0.96$ & $45.60 \pm 1.24$ & $49.63 \pm 1.34$ & $42.50 \pm 1.17$ & $46.32^{\mathrm{B}} \pm 0.59$ & & & & & & & \\
\hline Overall mean & $37.49 \pm 1.70$ & $36.80 \pm 1.58$ & $38.68 \pm 1.75$ & $35.10 \pm 1.74$ & & & & & & & & \\
\hline
\end{tabular}


Int.J.Curr.Microbiol.App.Sci (2018) 7(7): 773-782

\begin{tabular}{|c|c|c|c|c|c|c|c|c|c|c|c|c|}
\hline WinterMean & $37.22 \pm 0.67$ & $33.14 \pm 0.79$ & $33.03 \pm 0.81$ & $32.67 \pm 0.92$ & $33.01^{\mathrm{A}} \pm 0.40$ & 0.001 & $<0.01$ & $<0.01$ & $<0.01$ & 0.106 & $<0.01$ & $<0.01$ \\
\hline $\begin{array}{l}\text { Summer } \\
\text { Mean }\end{array}$ & $62.98 \pm 1.75$ & $61.57 \pm 1.33$ & $63.37 \pm 1.09$ & $59.56 \pm 1.5$ & $66.25^{\mathrm{B}} \pm 0.74$ & & & & & & & \\
\hline Overall mean & $48.92^{\mathrm{b}} \pm 2.24$ & $47.18^{\mathrm{b}} \pm 2.22$ & $48.28^{\mathrm{b}} \pm 2.29$ & $45.66^{\mathrm{a}} \pm 2.05$ & & & & & & & & \\
\hline \multicolumn{13}{|c|}{ Plasma cortisol (ng/mL) } \\
\hline WinterMean & $1.18 \pm 0.17$ & $1.14 \pm 0.09$ & $1.21 \pm 0.19$ & $1.04 \pm 0.11$ & $1.14^{\mathrm{A}} \pm 0.07$ & 0.015 & 0.001 & $<0.01$ & 0.133 & 0.972 & 0.06 & 0.995 \\
\hline $\begin{array}{l}\text { Summer } \\
\text { Mean }\end{array}$ & $3.19 \pm 0.19$ & $2.69 \pm 0.32$ & $2.93 \pm 0.24$ & $2.06 \pm 0.15$ & $2.72^{\mathrm{B}} \pm 0.12$ & & & & & & & \\
\hline Overall mean & $2.19^{\mathrm{b}} \pm 0.21$ & $1.92^{\mathrm{ab}} \pm 0.21$ & $2.07^{\mathrm{b}} \pm 0.21$ & $1.55^{\mathrm{a}} \pm 0.13$ & & & & & & & & \\
\hline
\end{tabular}

Basal diet with no supplementation $\left(\mathrm{T}_{1}\right)$ or supplemented with $\mathrm{I}_{2} @ 0.25 \mathrm{ppm}\left(\mathrm{T}_{2}\right), \mathrm{I}_{2} @ 0.5 \mathrm{ppm}\left(\mathrm{T}_{3}\right)$ and $\mathrm{Zn}(40 \mathrm{ppm}), \mathrm{Cr}(1.5 \mathrm{ppm}) \mathrm{Niacin}$ (600ppm) and Vit E (40ppm) in $\mathrm{T}_{4}$

ab/pqrs Means bearing different superscript in a row $(a b c)$ for treatment or Column (p,q,r,s) for period or (A,B) for seasons differ significantly $(\mathrm{P}<0.05)$ 
Respiration rate and rectal temperature is more sensitive indicator of summer stress reported by Lemerle and Goddard (1986). The increased respiration rate due to heat stress occurs by the stimulation of peripheral receptor by heat which trigger thermal centre in hypothalamus. Similar to our finding Taneja (1960) recorded increased respiration rate of during summer in comparison to winter in dairy cows. McLean (1963) showed that increase in respiration rate under summer stress in animal. Salem (1980) also showed an increase in RR of buffaloes and crossbreds cattle during summer compared to other seasons. Hahn (1899) demonstrated a strong positive correlation between respiration rate and surrounding temperature once it goes beyond $21^{\circ} \mathrm{C}$ (the rise in respiration rate @ $4.3 \mathrm{bpm}$ per ${ }^{\circ} \mathrm{C}$ above a baseline of $60 \mathrm{bpm}$ ).

\section{Plasma cortisol level}

The data on overall plasma Cortisol (ng/ml) levels estimated at in different season in growing crossbred calves have been shown in Table 3. Overall mean value of cortisol (ng/ $\mathrm{ml})$ was significantly $(\mathrm{P}<0.05)$ lower in $\mathrm{T}_{4}$ $\left(1.55^{\mathrm{a}} \pm 0.13\right)$ groups than $\mathrm{T}_{1}\left(2.19^{\mathrm{b}} \pm 0.21\right)$ group. But In winter season and summer season there is no significant difference observed among the treatment groups. However in season wise mean plasma cortisol (ng/ ml) levels was significantly $(\mathrm{P}<0.01)$ higher in summer $\left(2.72^{\mathrm{B}} \pm 0.12\right)$ as compare to winter $\left(1.14^{\mathrm{A}} \pm 0.07\right)$. In the present experiment, reduced cortisol value in treatment groups indicated that these animals had less stress compared to control group of calves. Plasma cortisol increased with increase in THI in all the four groups. It has been reported that cortisol level is affected by the thermal stress. Similar to our finding Patel (2015) supplemented 80 and 120 ppm zinc to pregnant $\mathrm{KF}$ cows and found significant $(\mathrm{P}<0.05)$ decrease in cortisol in supplemented group. Christinson and Johnson (1972) showed that moderate heat stress raises the plasma cortisol concentration from 30 to 37 $\mu \mathrm{g} /$ litre. The secretion of cortisol triggers physiological adjustments that make an animal to resist the stress caused by a warm environment. Habeeb et al., (2001) also reported increase cortisol concentration from 3.8 to $6.5 \mathrm{ng} / \mathrm{ml}$ when the calf is subjected to heat. Opposite to our finding Gudev (2007) did not record any significant change in plasma cortisol level by introducing the animals to heat stress.

This study concludes that the micronutrients are beneficial for comforts of animals and it should be altered according to season i.e. to decrease the stress levels of animal and increase efficiency

The results of present study suggest that the supplementation with chromium (1.5ppm ), naicin (600ppm ), vitamin E(40 ppm) and Zn were supplemented (40 ppm) ) in the ration of growing heifers during summer and winter stress period can ameliorate the effect of stress and minimize fiscal losses of the farmer.

\section{References}

Baumgard, L. H. and RhoadsJr, R. P. (2013). Effects of heat stress on post absorptive metabolism and energetics. Annu. Rev. Anim. Biosci., 1, 311-337

Benyo, Z., Gille, A., Bennett, C. L., Clausen, B. E. and Offermanns, S. 2006. Nicotinic acid-induced flushing is mediated by activation of epidermal langerhans cells. Molec.Pharmacy., 70: 1844-1849.

Bernabucci, U., Lacetera, N., Baumgard, L. H., Rhoads, R. P., Ronchi, B. and Nardone, A. (2010). Metabolic and hormonal acclimation to heat stress in domesticated ruminants. Animal.,4: 1167-1183. 
Blaxter, K.L. and Prince, H. 1945. Variation in some physiological activities of dairy cows. Vete. J., 101: 39-45

Christison, G.I and Johnson, H.D. 1972. Cortisol turnover in heat stressed cows. J.Anim.Sci., 35: 1005.

Di Costanzo, A., Spain, J.N. and Spiers, D.E. 1997. Supplementation of nicotinic acid for lactating Holstein cows under heat stress conditions. J. Dairy Sci., 80: $1200-1206$

Fuquay, J.W. 1981. Heat-stress as it affects animal production. J. Anim. Sci., 52: 164-174.

Gaalas, R.F. 1945. Effect of atmospheric temperature on body temperature and respiration rate of Jersycattle. J Dairy Res., 28: 555-563.

Gangwar, H. and Chandra, 1988. Studies on some physiological and some biochemical parameters of blood in cross bred bulls under tropical environment. M.Sc. Thesis, submitted to Deemed University, Indian Veterinary Research Institute, Izatnagar.

Gantner, V., Mijic, P., Kuterovac, K.,Solić, D. and Gantner, R. 2009.Temperaturehumidity index values and their significance on the daily production of dairy cattle. Mljekarstvo., 61: 56-63.

Gudev, D., Popova-Ralcheva, S., Moneva, P., Aleksiev, Y., Peeva, Tz.,Penchev, P. and Ilieva, I. 2007. Physiological indices in buffaloes exposed to sun. Archiva Zootec., 10: 123-127.

Habeeb, A.A.M., Aboulnaga, A.J. and Kamal, T.H. 2001. Heat-induced changes in body water concentration, Ts, cortisol, glucose and cholesterol levels and their relationships with thermoneutral body weight gain in Friesian calves. Proceedings of 2nd International Conference on Animal Production and Health in Semi-arid Areas. El-Arish, North Sinai, Egypt,97-108.
Johnson H.D., Shanklin M.D. and Hahn L.1986, Productive adaptability indices of Holstein cattle to environmental heat. Agri. For.and Mete., 33:291-297

Joshi, B.C., Joshi, H.B., Guha, S, Ahmad, M.S. 1982. Physiological responses of Murrah buffalo heifers to hot arid and hot humid microenvironment. J. of Vet.Physio.and Sci., 1: 34-40.

Kumar, S. 2013. Thermal Stress Alleviation And Immune Modulation In Sahiwal Calves Supplemented with Chromium Propionate. M.V.Sc Thesis, National Dairy Research Institute (Deemed University), Karnal India.

Mayengbam, P. 2008. Heat shock protein 72 expression in relation to thermotolerance of Sahiwal and Holstein-Friesian crossbred cattle. Ph.D. Thesis submitted to NDRI Deemed University, Karnal (Haryana), India.

Mclean, J.A. 1963. The regional distribution of cutaneous moisture vaporization in the Ayrshire calf. J. of Agri. Sci., 61: 275-280.

Nardone, A., Ronchi, B., Lacetera, N., Ranieri, M. S. and Bernabucci, U. 2010. Effects of climate changes on animal production and sustainability of livestock systems. Liv. Sci., 130: 57

Patel, B. 2015. Effect of Zinc supplementation on peri-parturient karan fries cows during hot humid condition. M.V.Sc Thesis, National Dairy Research Institute (Deemed University), Karnal, India.

Salem, I.A. 1980. Seasonal variations in some body reactions and blood constituents in lactating buffaloes and Friesian cows with reference to acclimatization. J. Egy.Vete.Medi. Assoc., 40: 63- 72.

Singh, G., Hooda, O. K., Mahapatra, R. K., Meur. S. K. and Varshney, V.P. 2009. 
Ameliorative effect of zinc and manganese supplementation in buffalo calves during hot climatic conditions. Indi. J. Anim. Sci., 79: 1153-1155

Taneja, G. C. 1960. Sweating in cattle. VI. Density of sweat glands and its relationship with cutaneous evaporation. J. Agric. Sci., 55:109-110.
Verma, D.N. and Husain, K.Q. 1986. Seasonal variation in rectal temperature, pulse and respiration rates of buffaloes in tropical climate. J. Vete. Physi.Alli. Sci., 5: 18-26

West J.W.2008. Interactions of energy and bovine somatotropin with heat stress. J. Dairy Sci., 77:2091-2108.

\section{How to cite this article:}

Gaurav Thorat, Anjali Khare, S.S. Lathwal, Mamata Joysowal, A. Aziz and Chander Datt. 2018 Effect of Dietary Micronutrients on Physiological Responses and Biochemical Profile in Growing Cross Bred Calves. Int.J.Curr.Microbiol.App.Sci. 7(07): 773-782. doi: https://doi.org/10.20546/ijcmas.2018.707.094 